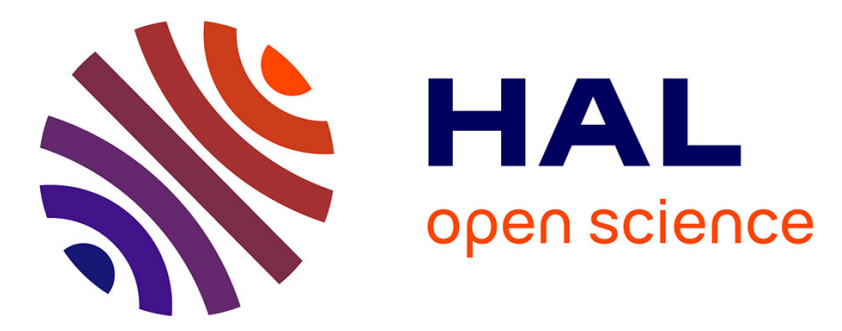

\title{
Proteomic investigation of enzymes involved in 2-ethylhexyl nitrate biodegradation in Mycobacterium austroafricanum IFP 2173.
}

Elodie Nicolau, Lauriane Kuhn, Rémy Marchal, Yves Jouanneau

\section{- To cite this version:}

Elodie Nicolau, Lauriane Kuhn, Rémy Marchal, Yves Jouanneau. Proteomic investigation of enzymes involved in 2-ethylhexyl nitrate biodegradation in Mycobacterium austroafricanum IFP 2173.. Research in Microbiology, 2009, 160 (10), pp.838-47. 10.1016/j.resmic.2009.09.017 . hal-01063096

\section{HAL Id: hal-01063096 \\ https://hal.science/hal-01063096}

Submitted on 12 Sep 2014

HAL is a multi-disciplinary open access archive for the deposit and dissemination of scientific research documents, whether they are published or not. The documents may come from teaching and research institutions in France or abroad, or from public or private research centers.
L'archive ouverte pluridisciplinaire $\mathbf{H A L}$, est destinée au dépôt et à la diffusion de documents scientifiques de niveau recherche, publiés ou non, émanant des établissements d'enseignement et de recherche français ou étrangers, des laboratoires publics ou privés. 
1 Proteomic investigation of enzymes involved in 2-Ethylhexyl nitrate biodegradation in

4 Elodie Nicolau ${ }^{\mathrm{a}, \mathrm{c}, \mathrm{d}}$, Lauriane Kuhn ${ }^{\mathrm{b}}$, Rémy Marchal $^{\mathrm{d}}$, Yves Jouanneau ${ }^{\mathrm{a}, \mathrm{c}}$ *

$7 \quad{ }^{\mathrm{a}}$ Laboratoire de Chimie et Biologie des Métaux and ${ }^{\mathrm{b}}$ Laboratoire d'Etude de la Dynamique des

8 Protéomes, CEA, iRTSV, 38054 Grenoble, France

$9 \quad{ }^{\mathrm{c}} \mathrm{CNRS}-\mathrm{UMR} 5249,38054$ Grenoble, France

10 dDépartement de Biotechnologie, Institut Français du Pétrole, 92852 Rueil-Malmaison Cedex, 11 France

16 Corresponding author :

Yves Jouanneau

LCBM/iRTSV, CEA-Grenoble

F-38054 Grenoble Cedex 9, France.

E-mail addresses : nicolau.elodie@gmail.com ; lauriane.kuhn@pansanel.net ; 


\section{$1 \quad$ Abstract}

2 2-Ethyhexyl nitrate (2-EHN) is a synthetic chemical used as a diesel fuel additive, which is

3 recalcitrant to biodegradation. In this study, the enzymes involved in 2-EHN degradation have 4 been investigated in Mycobacterium austroafricanum IFP 2173. Using two-dimensional gel 5 electrophoresis and a shotgun proteomic approach, a total of 398 proteins appeared to be more 6 abundant in cells exposed to 2-EHN than in acetate-grown cells. This set of proteins includes 7 multiple isoenzymes of the $\beta$-oxidation pathway, two alcohol and one aldehyde dehydrogenases, 8 as well as four cytochromes P450, including one CYP153 which functions as an alkane 9 hydroxylase. Strain IFP 2173 was also found to contain two alkB-like genes encoding putative 10 membrane-bound alkane hydroxylases. RT-PCR experiments showed that the gene encoding the 11 CYP153 protein, as well as the alkB genes, were expressed on 2-EHN. These findings are

12 discussed in the light of a recently proposed 2-EHN degradation pathway, involving an initial 13 attack by an alkane hydroxylase and one turn of $\beta$-oxidation, leading to the accumulation of a $\gamma$ 14 lactone as a dead-end product.

16 Keywords : alkane hydroxylase; cytochrome P450; CYP153; 2-ethylhexyl nitrate; 17 Mycobacterium austroafricanum; $\beta$-oxidation.

19 Abbreviations : ADH : alcohol dehydrogenase ; ALDH : aldehyde dehydrogenase ; 2-EHN : 2ethylhexyl nitrate ; SDR : short-chain dehydrogenase/reductase 
2-Ethylhexyl nitrate (2-EHN) is a xenobiotic compound used as a gasoline additive. Due to

3 its explosive properties, 2-EHN is considered as the best cetane improver for diesel oil, including

4 bio-diesels that might be used in the near future [1;25]. In case of accidental release, 2-EHN is a

5 serious health hazard, as humans exposed to this chemical were found to suffer from various

6 symptoms, including headache, dizziness, chest discomfort, palpitations or nausea [7]. Although

7 2-EHN was considered not readily biodegradable by US EPA [26]), it was recently reported that

8 it could be degraded by Mycobacterium austroafricanum [24].

9 Soil Mycobacteria have been described for their ability to degrade a wide range of aliphatic

10 and aromatic hydrocarbons, including polycyclic aromatic hydrocarbons [3; 10; 33], and fuel

11 additives such as methyl tertio-butyl-ether [5; 13]. These bacteria are well equipped to degrade

12 hydrocarbons, which they used as carbon sources. Their bacterial wall, rich in mycolic acids,

13 confers resistance to toxic hydrophobic pollutants and, on the other hand, may facilitate access to

14 hydrocarbons [12; 22]. Moreover, soil Mycobacteria contain oxygenases of different types,

15 which play a crucial role in the degradation of both aliphatic and aromatic hydrocarbons. For

16 instance, monooxygenases catalyze the first step in the degradation of alkanes. $\mathrm{C}_{5}-\mathrm{C}_{16}$ alkanes are

17 substrates of two kinds of enzymes, either integral-membrane non-heme diiron monooxygenases

18 (AlkB) [29], or cytochromes P450 [14]. Growth on alkanes requires metabolic adaptation, as

19 shown through a proteomic analysis of the marine bacterium Alcanivorax borkumensis SK2 [18].

20 This study revealed that alkane utilisation may proceed via different pathways, involving two

21 AlkB hydroxylases, one putative flavin monooxygenase, and three P450 cytochromes. Moreover,

22 bacterial adaptation to alkane utilisation resulted in a strongly modified metabolism, with

23 consequences for carbon flow and membrane lipid composition [18]. In recent years, high-

24 throughput proteomics was implemented to identify whole sets of enzymes involved in complex

25 bacterial metabolic pathways, such as the biodegradation of aromatic hydrocarbons [9]. 
1 Combined with functional genomics, proteomics helps understand cell response to environmental

2 stimuli and may prove useful to develop efficient bioremediation strategies [34].

3 In previous studies, M. austroafricanum IFP 2173 was isolated on iso-octane [23], then

4 selected for its ability to degrade 2-EHN [24]. Degradation of 2-EHN was found to be

5 incomplete, yielding a 6-carbon $\gamma$-lactone, which accumulated as a dead-end product. A

6 degradation pathway was proposed involving hydroxylation of the methyl group in distal

7 position, then oxidation to the carboxylic acid, and further metabolism through one cycle of $\beta$ -

8 oxidation [17]. In order to identify the enzymes involved in this pathway, we have undertaken a

9 proteomic analysis of cells exposed to 2-EHN. Because the genome sequence of strain IFP 2173

10 is unknown, we tentatively identified relevant proteins by comparing their peptide sequences to

11 those of orthologs found in the data bases. Currently, 21 genome sequences of Mycobacterium

12 strains are available, six of which are from fast-growing strains isolated from soil, and genome

13 annotation of $M$. smegmatis and related species has been assessed by proteomic analysis [6].

14 Besides focusing on enzymes involved in 2-EHN degradation, this study gives an insight into

15 proteins possibly involved in the response of bacteria to exposure to a toxic and hydrophobic

16 xenobiotic compound.

\section{2. Material and Methods}

192.1 Bacterial strain and growth conditions

20 M. austroafricanum strain IFP 2173 was grown on a mineral salts medium at $30^{\circ} \mathrm{C}$ as described

21 previously [17]. The carbon source was sodium acetate (4 g/l) or 2-EHN (500 mg/l). Growth was

22 monitored by measurements of the optical density (OD) at $600 \mathrm{~nm}$. To prepare 2-EHN-induced

23 cells, acetate-grown cells were washed and resuspended to an $\mathrm{OD}_{600}$ of 1.5 in culture medium,

24 then incubated for five days with 2-EHN in conical flasks sealed with Teflon-coated screw caps. 
$1 \quad 2.2$ In vivo ${ }^{35}$ S labelling of proteins

2 For labelling experiments, bacteria were incubated with 2-EHN or acetate (control) in the

3 presence of a mixture of ${ }^{35} \mathrm{~S}$-labelled methionine and cysteine $(0.1 \mathrm{mCi}$, Easytag Express protein-

4 labelling mix; NEN Life Science Products). Bacteria were incubated for $6 \mathrm{~h}$ on acetate or $30 \mathrm{~h}$

5 on 2-EHN at $30^{\circ} \mathrm{C}$. In a control experiment, bacteria were incubated without exogenous C-source

6 for 30h. Protein extracts were prepared as described below and analyzed by 2D electrophoresis

7 and SDS-PAGE.

$8 \quad 2.3$ Preparation of protein extracts

9 Cell-free extracts were prepared by ultrasonication as described previously [10].

10 Ultracentrifugation at $240,000 \times g$ for $1 \mathrm{~h}$ was performed to separate soluble proteins from the

11 membrane fraction, using an Optima TLX Ultracentrifuge (Beckman Instruments). Supernatant

12 fractions were treated with benzonase (2,000 U; Merck), and subsequently dialysed for 4-5 h at

$1344^{\circ} \mathrm{C}$ against $5 \mathrm{mM}$ phosphate buffer, $\mathrm{pH} 7.5$, containing $1 \mathrm{mM} \mathrm{MgCl}_{2}$, then overnight against

14 ultrapure water. Samples were immediately processed as described below or stored at $-20^{\circ} \mathrm{C}$.

$15 \quad 2.4$ Two dimensional gel electrophoresis

16 Two-dimensional (2D) gel electrophoresis was carried out as described previously [10], with

17 minor modifications. Briefly, $400 \mu \mathrm{g}$ protein samples (or labelled extracts equivalent to $4.210^{4}$

$18 \mathrm{cpm}$ ) were applied to 18 -cm IPG strips (ReadyStrip; Biorad) and fractionated in the pH range 4

19 to 7 by isoelectric focusing for a total of approximately $70 \mathrm{kVh}$. Second dimension

20 electrophoresis was carried out on $12.5 \%$ polyacrylamide gels in a Protean II xi cell (Biorad) at

$2120 \mathrm{~mA}$ per gel for 15-16 h, using a Tris-glycine buffer system [11]. The proteins were visualised

22 by colloidal blue G-250 staining as described by Neuhoff [16], except that ethanol replaced

23 methanol. ${ }^{35} \mathrm{~S}$ labelled gels were stained, dried, and exposed to X-ray films for 3 weeks (Kodak

24 BioMax MR). All gels were performed in triplicate, except for gels containing labelled proteins.

25 Comparison of 2D gel patterns and spot intensities was carried out by visual inspection of gels. 
1 Only spots that were absent in control extracts or that repeatedly showed an estimated intensity at

2 least twice as high on 2-EHN extracts compared to control extracts were taken into consideration.

3 Protein spots of interest were excised from the gel and processed for in-gel protein digestion and

4 LC-MS/MS analysis as described below. Proteins up-regulated in acetate-grown cells are not

5 discussed in this study.

$6 \quad 2.5$ SDS-PAGE of membrane fractions

7 Protein pellets from high speed ultracentrifugation were homogenized in a volume equivalent to

$8 \quad 1 / 10$ the initial volume of extract with $25 \mathrm{mM}$ HEPES $\mathrm{pH} 7.5$, containing $10 \%$ of ethylene

9 glycol. Protein samples were adjusted to $1 \%$ SDS, $2.5 \% \beta$-mercaptoethanol, $10 \%$ glycerol, $10 \quad 0.001 \%$ bromophenol blue and $150 \mathrm{mM}$ Tris-HCl, $\mathrm{pH}$ 7.0, prior to separation by SDS-PAGE on 11 a $12.5 \%$ polyacrylamide gel in a Tris-Tricine buffer system [20]. Proteins were stained with 12 colloidal blue G-250 as described above.

\subsection{Protein digestion}

14 Protein bands were manually excised from the gels and processed in 96-well microtitration plates 15 using an automatic platform (EVO150, Tecan). For shotgun analysis, the protein track resulting 16 from SDS PAGE was cut into 13 slices. Gel slices were washed in $25 \mathrm{mM} \mathrm{NH}_{4} \mathrm{HCO}_{3}$ for 15 min 17 and then in $50 \%(\mathrm{v} / \mathrm{v})$ acetonitrile containing $25 \mathrm{mM} \mathrm{NH} \mathrm{HCO}_{3}$ for $15 \mathrm{~min}$. This washing 18 procedure was repeated three times. Gel pieces were then dehydrated with $100 \%$ acetonitrile and 19 then incubated with $7 \% \mathrm{H}_{2} \mathrm{O}_{2}$ for $15 \mathrm{~min}$ before being washed again as described above. $0.15 \mu \mathrm{g}$ 20 of modified trypsin (Promega, sequencing grade) in $30 \mu \mathrm{l}$ of $25 \mathrm{mM} \mathrm{NH}_{4} \mathrm{HCO}_{3}$ was added to each 21 gel slice for an overnight incubation at $37^{\circ} \mathrm{C}$. Peptides were then extracted from gel pieces in 22 three 15 min sequential extraction steps in $30 \mu \mathrm{L}$ of $50 \%$ acetonitrile, $30 \mu \mathrm{L}$ of $5 \%$ formic acid 23 and finally $30 \mu \mathrm{L}$ of $100 \%$ acetonitrile. The pooled supernatants were then dried under vacuum. 
2 For nano-LC-MS/MS analysis, the dried extracted peptides were resuspended in water containing

$32.5 \%$ acetonitrile and $2.5 \%$ trifluoroacetic acid. A nano-LC-MS/MS analysis was then 4 performed (Ultimate 3000, Dionex and LTQ-Orbitrap, Thermo Fischer Scientific). The system 5 included a $300 \mu \mathrm{m}$ x $5 \mathrm{~mm}$ PepMap C18 precolumn and a $75 \mu \mathrm{m}$ x $150 \mathrm{~mm} \mathrm{C18} \mathrm{Gemini} \mathrm{column.}$

6 The column was developed at a flow rate of $300 \mathrm{~nL} / \mathrm{min}$ with a 60 -minute gradient from solvent 7 A (5\% acetonitrile and $0.1 \%$ formic acid in water) to solvent $\mathrm{B}(80 \%$ acetonitrile and $0.08 \%$ 8 formic acid in water). MS and MS/MS data were acquired using Xcalibur (Thermo Fischer

9 Scientific) and processed automatically using Mascot Daemon software (Matrix Science).

10 Consecutive searches against the SwissProt/TrEMBL database were performed for each sample 11 using an intranet version of Mascot 2.0. Peptide modifications allowed during the search were N12 acetylations, mono- and dioxidations (methionine), conversions to cysteic acid and methionine 13 sulphone. Proteins showing at least two peptides with a score higher than the query threshold (p14 value $<0.05$ ) were automatically validated. If one set of peptides yielded two or more proteins, 15 and proteins were from the same organism, only the protein ranked first in the alphabetic order 16 was validated (rejection of redundant proteins). When the proteins were from different 17 Mycobacterium strains, that from M. vanbalenii PYR-1 was arbitrarily chosen. Proteins identified 18 by only one peptide were checked manually using the classical fragmentation rules. The rate of 19 false-positive protein identifications was estimated to be about $1.2 \%$ by performing a search with 20 a SwissProt/TrEMBL decoy database according to a published procedure [4].

21 For each identified protein, the spectral count values were determined, and abundance rates were 22 then calculated as percentages of the whole set of identified proteins according to the formula :

23 Abundance of protein $X=($ spectral count protein $X) /(\Sigma$ spectral counts for all proteins $) \times 100$. 
2 DNA fragments containing alkB1 alone, alkB1-rubA1-rubA2, alkB1-rubA1-rubA2-tetR, and

3 alkB2 were separately PCR-amplified using appropriate primers and genomic DNA from 4 IFP2173 prepared as previously described [8]. CYP153 was amplified using 5'-

5 GCATATGACCGAAATGACGGTG and 5'-CGGATCCTCAGGCGTTGATGCGCAC as

6 forward and reverse primers, respectively. The amplicons were purified, cloned into pDRIVE

7 (Qiagen) and sequenced on both strands. Gene sequences were validated when sequencing of

8 replicate amplicons gave identical results. Details on the amplification and cloning procedures

9 are available upon request. Sequence analysis was performed using BLAST.

\section{$10 \quad 2.9$ RNA extraction and RT-PCR analysis}

11 Total RNA was extracted from 50-mL cultures of strain IFP 2173 using standard procedures

12 [19]. Bacteria were grown on acetate to an $\mathrm{OD}_{600}$ of 0.7 (control cells) or washed and

13 resuspended to an $\mathrm{OD}_{600}$ of 0.6 , and further incubated with 2-EHN for four days. Bacteria were

14 then centrifuged at $10,000 \times \mathrm{g}$, and resuspended in $200 \mu \mathrm{L}$ of $20 \mathrm{mM}$ Tris-HCl, $5 \mathrm{mM}$ EDTA, $15 \mathrm{pH} \mathrm{8,} \mathrm{containing} \mathrm{lysozyme} \mathrm{and} \mathrm{lysostaphin,} 1.5$ and $0.025 \mathrm{mg} / \mathrm{mL}$, respectively (Sigma Life 16 Science). After 10 min at $37^{\circ} \mathrm{C}$, RNA was extracted using the RiboPure ${ }^{\mathrm{TM}}$-Bacteria kit (Ambion, 17 Austin, Texas). Crude RNA samples $(2 \mu \mathrm{g})$ were treated with Turbo DNase (Ambion) and the 18 resulting RNA preparations were quantified using a Nanodrop apparatus (NanoDrop 19 Technologies). RT-PCR was performed with $10 \mathrm{ng}$ of RNA preparation using the One step RT-

20 PCR kit (Promega, France). PCR amplification of internal gene sequences was carried out with 21 the following primer pairs: for alkB1, alkB1-F (5'-CGTGATCATGGGTGCCTAC-3') and 22 alkB1-R (5'-CCAGAACGTCTCACCGAAG-3'); for alkB2, alkB2-F (5'23 CCTGATGTTCCTCGTGATCC-3') and alkB2-R (5'-CTTGTCGACGTCGCTCATC-3'); for 24 CYP153, P450fw1 and P450rw3 [30]; for the aldehyde dehydrogenase encoding gene (alkH), 
1 CCAGGCGATGCGCTTGGCG-3'), for the 16S RNA gene, P16S-F (5'-

2 GGTCTAATACCGAATACACCCTTCT-3') and P16S-R (5'-CCAGGAATTCCAGTCTCCC-

$\left.33^{\prime}\right)$. RT-PCR reactions were carried out as follows: $45 \mathrm{~min}$ at $45^{\circ} \mathrm{C}, 3 \mathrm{~min}$ at $95^{\circ} \mathrm{C}$, then 32 cycles

4 of $30 \mathrm{~s}$ at $95^{\circ} \mathrm{C}, 30 \mathrm{~s}$ at $62^{\circ} \mathrm{C}$ and $30 \mathrm{~s}$ at $72^{\circ} \mathrm{C}, 5 \mathrm{~min}$ final elongation at $72^{\circ} \mathrm{C}$. Products were

5 analyzed by electrophoresis on $2 \%$ agarose gels.

62.10 Nucleotide sequences

7 The nucleotide sequences of alkB1rubA1rubA2tetR, alkB2, CYP153, alkH (partial) were

8 deposited under accession number FJ009005, FJ009004, FJ009003, FJ207472, respectively.

\section{3. Results}

103.1 Identification of cytoplasmic proteins up-regulated on 2-EHN

11 In order to identify proteins up-regulated on 2-EHN, protein profiles of cells incubated with this

12 compound were compared to those of cells grown on acetate. Cytoplasmic proteins were

13 prepared and analysed by 2D gel electrophoresis while membrane fractions from the high-speed

14 centrifugation pellet of cell extracts were separated by SDS-PAGE. As discussed below,

15 membrane fractions possibly included proteins loosely associated to membranes as well as

16 cytoplasmic proteins trapped into membrane vesicles.

17 Comparison of $2 \mathrm{D}$ gel protein profiles revealed that 30 protein spots were either absent in 18 acetate-grown cells or at least two-fold more abundant in 2-EHN-grown cells (Fig. 1). To

19 confirm these results, we performed ${ }^{35}$ S-labeling experiments where cells were exposed to 2-

$20 \mathrm{EHN}$ for $30 \mathrm{~h}$ or to acetate for $6 \mathrm{~h}$. This difference in incubation time was intended to reflect the 21 much slower growth of strain IFP 2173 on 2-EHN compared to acetate. Autoradiographies of the

22 2D gel showed markedly different patterns (Fig. S1 in supplementary data). Most labelled

23 proteins uniquely detected in 2-EHN-exposed cells corresponded to spots previously identified

24 based on comparison of stained gels, but two additional 2-EHN-specific polypeptides were found

25 (E10 and E28). The position of these extra polypeptides has been reported on the 2D image in 
1 Fig. 1A. The 32 protein spots of interest were subjected to trypsin digestion followed by LC-

2 MS/MS analysis and search for peptide matches in the data bases using Mascot (see Materials

3 and Methods for details). Thanks to the high accuracy and wide dynamic range of the mass

4 spectrometer, several spots were found to contain 2- to 4 imperfectly separated proteins. Spots

5 E2, E3, E4, E7, E12, E18, E22 and E24 yielded two protein identifications, spots E1, E9 and E10

6 yielded three and spot E23 gave four. On the other hand, a few pairs of closely-located spots

7 gave single protein identifications. As a result, the analysis of 32 spots ended up with a total of

842 proteins, which matched orthologs found in M. vanbalenii PYR-1 and related Mycobacterium

9 strains from soil (Table 1). One set of induced proteins was clearly associated with the $\beta$ -

10 oxidation of fatty acids. Some of the enzymes involved in this pathway were found in multiple

11 isoforms, including acetyl-CoA acyltransferase (2 copies), acyl-CoA dehydrogenase (7 copies), enoyl-CoA hydratase/isomerase (4 copies). Consistent with this finding, the reference

13 Mycobacterium strains mentioned above were found to contain multiple gene copies coding for

14 enzymes of the $\beta$-oxidation in their genome (Table S1). Other proteins up-regulated on 2-EHN

15 included dehydrogenases, diverse metabolic enzymes and proteins involved in cell response to 16 stress (Table 1).

\subsection{2-EHN-induced proteins associated to membrane fractions}

19 Since membrane proteins are generally difficult to analyze by regular 2D gel electrophoresis, we

20 chose to separate the proteins of the insoluble high-speed fractions of cell extracts by one

21 dimension SDS-PAGE. When stained protein profiles of 2-EHN versus acetate-grown cells were

22 compared no obvious differences were observed. However, ${ }^{35} \mathrm{~S}$ radioactive labelling revealed that

23 some protein bands became clearly labelled upon exposure to 2-EHN, including a prominent 45-

$24 \mathrm{kDa}$ protein (Fig. S2). In order to identify proteins of interest, protein sets from 2-EHN and

25 acetate grown cells were separated by SDS-PAGE, and subjected to trypsin-digestion and peptide 
1 analysis by LC-MS/MS. Data processing using Mascot identified over 1300 proteins, most of

2 which had counterparts in the proteome of M. vanbalenii PYR-1. Search for membrane-bound

3 proteins using the HMMTOP software [27] revealed that about $30 \%$ of this set of proteins

4 potentially showed at least one transmembrane segment. In addition, an unknown proportion of

5 the detected proteins were probably membrane-associated through hydrophobic interactions or as

6 part as membrane-bound complexes However, many proteins recovered in the membrane fraction

7 were cytoplasmic, indicating that they might have been trapped in membrane vesicles that

8 formed upon cell lysis.

9 An inventory of proteins found to be common or specific to cells incubated with 2-EHN or

10 acetate is presented in tables S2 and S3 in supplementary material. From the set of common

11 proteins, a subset was selected based on abundance rates more than twice as high for the 2-EHN

12 treated cells as compared to control cells. The proteins of this subset (65 proteins) as well as

13 those found to be specific to the 2-EHN treatment (300 proteins) were tentatively classified in

14 terms of enzyme category or metabolic function, with special emphasis on enzymes related to

15 alkane degradation (Table 2). A comparison of this set of proteins with that found by the 2D gel

16 analysis revealed that only 9 proteins were common to both sets (Table 1). A total of 17 proteins

17 were found to be enzymes of the $\beta$-oxidation of fatty acids, including many redundant isoforms,

18 five of which were also detected on 2D gels (A1TCG6, A1TDA6, A1T5U2, A1TE56 and

19 A1TDW4). Consistent with the 2D gel data, numerous proteins up-regulated on 2-EHN were

20 dehydrogenases including 12 short-chain dehydrogenase/reductases (SDR). Several proteins

21 were likely involved in the response to stress, other presumably act as transcriptional regulators.

22 The analysis highlighted two alcohol dehydrogenases (ADH) and one aldehyde dehydrogenase

23 (ALDH) possibly implicated in the early steps of the 2-EHN degradation pathway (see below).

24 Besides, enzymes of the central metabolism previously shown to be essential for alkane

25 assimilation [18] have been detected, including two phosphoenolpyruvate synthases involved in 
1 gluconeogenesis. Enzymes related to the metabolism of lipids were also identified, suggesting

2 that membrane modifications might occur as part of the bacterial adaptation to growth on a

3 hydrophobic substrate.

4 Four cytochromes P450 were identified, two of which belong to the CYP153 subclass of P450,

5 potentially capable of alkane hydroxylation. The most abundant of the two enzymes, identified

6 by 11 peptides (36\% coverage), was found to be closely related to the CYP153 enzyme from

$7 \quad$ Mycobacterium sp. XHN-1500 [31].

8 Membrane proteins relevant to the metabolism of alkanes were not detected in either protein

9 extract. This is the case for the trans-membrane AlkB hydroxylase that is known to catalyze the

10 initial oxidation reaction of alkanes in many bacteria [29].

\subsection{Occurrence of several putative alkane monooxygenases in strain IFP 2173}

13 Our proteomic analysis revealed that one cytochrome P450 with close similarity with a well 14 characterized alkane hydroxylase (CYP153) was 2-EHN-specific. In order to learn more about 15 this protein, its structural gene was PCR-amplified using genomic DNA from strain IFP 2173 and 16 specific oligonucleotides designed based on the gene sequence of CYP153A from strain XHN-

171500 [31]. A 1261 bp gene was obtained, which displayed high sequence similarity with its 18 counterpart from strain XHN-1500 (99\% identities), resulting in a predicted protein having only

19 two amino acid changes compared to CYP153A.

20 In a previous study, a gene potentially involved in isoalkane degradation was found in strain IFP

212173 and identified as an alkB gene based on partial sequence determination [23]. A BLAST 22 search showed than this gene was closely related to alkB from $M$. vanbaalenii PYR-1. This strain 23 has two alkane monooxygenase genes, one of which is associated with two genes encoding 24 rubredoxins. Primers were designed after the alkB gene sequences of $M$. vanbaalenii PYR-1, and 25 used to amplify corresponding genes from strain IFP 2173 genomic DNA. Two alkB-like genes 
1 were found in two separate loci, which displayed exactly the same gene arrangement as that

2 found in $M$. vanbaalenii PYR-1. In particular, the alkB1 gene was followed by two rubredoxin

3 genes, named rubA1 and rubA2, almost identical to counterpart genes of $M$. vanbaalenii PYR-1

4 (99\% identity). The second alkB gene (alkB2) was 98\% identical to its counterpart in strain PYR-

51.

63.4 RT-PCR evidence for the expression of three alkane hydroxylases in 2-EHN fed cells

7 Since none of the AlkB-like hydroxylases was detected in extracts of strain IFP 2173 upon

8 proteomic analysis, we carried out RT-PCR experiments to determine whether the corresponding

9 genes were expressed under the growth conditions used in this study. Transcripts of the alkB1

10 and alkB2 genes were equally detectable in acetate and 2-EHN-fed cells (Fig. 2). Further analysis

11 showed that a transcript specific for the gene encoding the CYP153 hydroxylase described above

12 was also detected in both 2-EHN and acetate-grown cells (Fig. 2). This finding is consistent with

13 the fact that the enzyme was clearly identified by proteomic analysis in 2-EHN-fed cells but

14 contrasted with the finding that it was not found in acetate-grown cells. Perhaps cells growing on

15 acetate produce the CYP153 protein at a low level or in a transient manner during a particular

16 phase of growth, so that it passed undetected.

17 A single ALDH appeared to be up-regulated in 2-EHN-fed cells to a level at least 2-fold as high

18 as in acetate-grown cells. Using primers designed after the gene encoding an orthologous ALDH

19 from strain PYR-1 (A1P1A6), a DNA fragment that perfectly matched the target gene sequence,

20 was PCR-amplified from IFP 2173 genomic DNA. RT-PCR indicated that this gene was

21 transcribed in both acetate and 2-EHN fed cells (Fig. 2). The deduced sequence of the closely

22 related PYR-1 enzyme displayed 39\% sequence identity with the product of the alkH gene from

23 P. putida GPo1. 


\section{4. Discussion}

2 The present study deals with the metabolic adaptation of a bacterium which was forced to grow

3 on a xenobiotic compound being a poor carbon source and a toxic substance. Our proteomic

4 analysis identified over 1300 proteins based on sequence information available in the data bases

5 even though the genome of strain IFP 2173 was unknown. Most proteins were identified as

6 orthologs from strain M. vanbaalenii PYR-1 or related Mycobacterium species, thus reflecting

7 the high degree of conservation of protein sequences in the proteomes from fast-growing

8 Mycobacterium species isolated from various places around the world. Besides catabolic

9 enzymes enabling the bacterium to utilize 2-EHN as carbon source, many up-regulated proteins

10 were found to be involved in lipid metabolism, regulation and response to stress, and might help

11 bacteria to adapt to the toxic and/or hydrophobic character of 2-EHN. The following discussion

12 focuses on enzymes that might be implicated in 2-EHN degradation.

13 In a previous study, we showed that strain IFP 2173 partially degraded 2-EHN to a compound 14 identified as 4-ethyltetrahydrofuran-2(3H)-one, and we proposed a degradation pathway outlined

15 in figure 3 [17]. Every step in the pathway can be assigned at least one enzyme found among the

16 proteins up-regulated on 2-EHN, except for the last step of the $\beta$-oxidation which is catalyzed by

17 a thiolase. Since three thiolase genes are present in the genomes of three related Mycobacterium

18 species (Table S1), at least one thiolase is expected to be produced by strain IFP 2173 grown on

19 2-EHN. Perhaps, the enzyme was synthesized in small amounts and passed undetected in our

20 proteomic analysis.

21 We identified four alkane hydroxylases that might catalyze the first step in 2-EHN degradation

22 i.e. the hydroxylation of the distal methyl group. Two enzymes are similar to the classical AlkB

23 membrane-bound enzymes that were found to play a pivotal role in alkane degradation by $P$.

24 putida GPo1 [28] and A. borkumensis SK2 [21]. The AlkB proteins were not detected in the

25 membrane fraction of IFP 2173 in either growth conditions, even when searching the proteomic 
1 data for the expected peptides derived from their deduced protein sequence. Nevertheless,

2 specific transcripts for the corresponding genes were found in cells grown on acetate or exposed

3 to 2-EHN suggesting that the proteins were synthesized. Perhaps, the AlkB proteins were poorly

4 solubilized in SDS or yielded few tryptic peptides detectable by LC-MS/MS. The two other

5 plausible enzymes that can initiate 2-EHN degradation are soluble cytochromes P450 of the

6 CYP153 subfamily. Although many genes encoding cytochromes P450 are present in the

7 genomes of related Mycobacterium species (Table 2), sequence alignments indicated that none of

8 the gene products was related to the CYP153 (data not shown). In addition, the CYP153 proteins

9 identified in strain IFP 2173 were found to be mainly produced on 2-EHN, suggesting that at

10 least one of these enzymes takes part in the degradation. CYP153 cytochromes hydroxylate linear

11 or cyclic alkanes with medium chain length [31]. For instance, the CYP153A6 from

12 Mycobacterium sp. XHN1500, which is the closest ortholog of the major CYP153 from IFP

13 2173, preferentially utilizes octane [31], but can also hydroxylate substrates with a bulky

14 structure like limonene [31]. CYP153-like genes have been found in other Actinomycetes as well

15 as in $\alpha$ and $\beta$-proteobacteria, and three groups were distinguished based on phylogenetic

16 considerations [29]. Like other bacterial cytochromes, the CYP153 enzymes function with two

17 electron carriers, a NAD(P)H-oxidoreductase and a ferredoxin. In this respect, a FAD-binding

18 oxidoreductase that might be functionally associated with one of the CYP153 from IFP 2173 has

19 been identified by the 2D gel approach (Table 1), and four such reductases were detected by the

20 shotgun approach (Tables S2 \& S3).

21 An esterase is also required to hydrolyze the nitro-ester bond of 2-EHN. A chloride peroxidase

22 was found among the 2-EHN-induced proteins in the 2D gel analysis (A1T5E7), which showed

23 the classical consensus sequence ( $\mathrm{G} X \mathrm{~S} X \mathrm{G})$ typical for the active site of esterases. This type of

24 enzyme is active on carboxylic esters [2], but it is unknown whether it could remove the nitro

25 group of 2-EHN. Four other putative esterases up-regulated on 2-EHN can potentially catalyze 
1 this reaction (Tables S2 \& S3). Since strain IFP 2173 can use 2-ethylhexanol and transform it to

2 2-ethylhexanoic acid and 4-ethyltetrahydrofuran-2(3H)-one [17], it may be inferred that

3 hydrolysis of the ester bond precedes the hydroxylation of the distal methyl group in the

4 biodegradation pathway.

5 The subsequent step in the degradation pathway is the conversion of the 2-ethylpentane-1,5-diol

6 to an aldehyde by an $\mathrm{ADH}$. Three $38-\mathrm{kDa} \mathrm{ADH}$ were apparently associated to 2-EHN

7 metabolism, which are predicted to have a zinc-binding domain and a GroES-like structure. A

8 different and larger ADH (AlkJ; $61 \mathrm{kDa})$ is involved in alkane oxidation in P. putida GPo1.

9 However, a deletion of alkJ did not affect alkane degradation, indicating that this reaction does

10 not require a specific $\mathrm{ADH}[28]$.

11 A single 2-EHN-specific ALDH was detected by SDS-PAGE and peptide analysis. Examination

12 of the sequence of the orthologous enzyme of strain PYR-1 (A1T1A6) showed that it might be

13 composed of a catalytic domain and a LuxC-like domain [15]. The detected ALDH showed $39 \%$

14 sequence identity with AlkH encoded by the alk operon, which is involved in alkane

15 biodegradation in P. putida GPo1 [32].

16 The biosynthesis of multiple isoenzymes of the $\beta$-oxidation pathway in response to cell exposure

17 to 2-EHN is intriguing. Many Mycobacterium species are known to thrive on alkanes, but the

18 redundancy of $\beta$-oxidation enzymes had not been previously reported, although it could be

19 predicted from the abundance of genes coding for such enzymes in available genome sequences

20 of Mycobacteria (Table S1). In contrast, the hydrocarbonoclastic bacterium A. borkumensis SK2

21 produced relatively few specific enzymes when growing on alkanes [18]. Perhaps, the greater

22 number of isoenzymes found in soil Mycobacteria reflects a more versatile metabolism, adapted

23 to a diet made of diverse hydrocarbons present in their environment.

24 In our study, we identified most of the enzymes possibly involved in 2-EHN degradation by 25 strain IFP 2173. Since these enzymes have counterparts in other soil Mycobacteria, the question 
1 arises whether these bacteria can degrade 2-EHN. We recently found that this ability is in fact

2 restricted to a few M. austroafricanum strains [21]. Hence, 2-EHN degradation might depend on

3 the catalytic activity of some specific enzyme such as a CYP153 hydroxylase, which is present in

4 strain IFP 2173 but absent in related Mycobacteria including strain PYR-1. Accordingly, we

5 observed that strain PYR-1 cannot utilize 2-EHN as carbon source (unpublished results).

6

7 Acknowledgements

8 This work was supported by grants from the Centre National de la Recherche Scientifique, the

9 Commissariat à l'Energie Atomique and University J. Fourier to UMR5249. E. Nicolau thanks

10 the Association Nationale de la Recherche Technique for a doctoral fellowship. We thank C.

11 Meyer and M. Louwagie for technical assistance and J. C. Willison for critical reading of the

12 manuscript. 


\section{$1 \quad$ References}

21 Ban-Weiss, G.A., Chen, J.Y., Buchholz, B.A., and Dibble, R.W. (2007). A numerical

3 investigation into the anomalous slight NOx increase when burning biodiesel; A new (old)

4 theory. Fuel Process. Technol. 88, 659-667.

52 Bornscheuer, U.T. (2002). Microbial carboxyl esterases: classification, properties and 6 application in biocatalysis. FEMS Microbiol. Rev. 26, 73-81.

73 Dean-Ross, D., and Cerniglia, C.E. (1996). Degradation of pyrene by Mycobacterium 8 flavescens. Appl Microbiol. Biotechnol. 46, 307-312.

94 Elias, J.E., and Gygi, S.P. (2007). Target-decoy search strategy for increased confidence

10 in large-scale protein identifications by mass spectrometry. Nature Methods 4, 207-214.

115 Francois, A., Mathis, H., Godefroy, D., Piveteau, P., Fayolle, F., and Monot, F. (2002).

12 Biodegradation of methyl tert-butyl ether and other fuel oxygenates by a new strain,

13 Mycobacterium austroafricanum IFP 2012. Appl. Environ. Microbiol. 68, 2754-2762.

146 Gallien, S., Perrodou, E., Carapito, C., Deshayes, C., Reyrat, J.M., Van Dorsselaer, A., 15 Poch, O., Schaeffer, C., and Lecompte, O. (2009). Ortho-proteogenomics: multiple proteomes 16 investigation through orthology and a new MS-based protocol. Genome Res. 19, 128-135.

177 Gołofit-Szymczak, M. (2005). 2-EHN Documentation. In: International Journal Of 18 Occupatioinal Safety dand Ergonomics, CIOP PIP, Warszawa, Czerniakowska.

198 Heiss-Blanquet, S., Benoit, Y., Marechaux, C., and Monot, F. (2005). Assessing the role 20 of alkane hydroxylase genotypes in environmental samples by competitive PCR. J Appl 21 .Microbiol. 99, 1392-1403.

229 Kim, S.J., Kweon, O., and Cerniglia, C.E. (2009). Proteomic applications to elucidate 23 bacterial aromatic hydrocarbon metabolic pathways. Curr. Opin. Microbiol. 12, 301-309. 
110 Krivobok, S., Kuony, S., Meyer, C., Louwagie, M., Willison, J.C., and Jouanneau, Y.

2 (2003). Identification of pyrene-induced proteins in Mycobacterium sp. strain 6PY1: evidence for

3 two ring-hydroxylating dioxygenases. J. Bacteriol. 185, 3828-3841.

411 Laemmli, U.K. (1970). Cleavage of structural proteins during the assembly of the head of

5 bacteriophage T4. Nature 227, 680-685.

612 Lee, M., Kim, M.K., Kwon, M.J., Park, B.D., Kim, M.H., Goodfellow, M., and Lee, S.T.

7 (2005). Effect of the synthesized mycolic acid on the biodegradation of diesel oil by Gordonia

8 nitida strain LE31. J. Biosci. Bioeng. 100, 429-436.

913 Lopes Ferreira, N., Maciel, H., Mathis, H., Monot, F., Fayolle-Guichard, F., and Greer,

10 C.W. (2006). Isolation and characterization of a new Mycobacterium austroafricanum strain, IFP

11 2015, growing on MTBE. Appl. Microbiol. Biotechnol. 70, 358-365.

1214 Maier, T., Forster, H.H., Asperger, O., and Hahn, U. (2001). Molecular characterization

13 of the 56-kDa CYP153 from Acinetobacter sp. EB104. Biochem. Biophys. Res. Commun. 286, $14 \quad 652-658$.

1515 Marchler-Bauer, A., Anderson, J.B., Derbyshire, M.K., DeWeese-Scott, C., Gonzales, 16 N.R., Gwadz, M., Hao, L., He, S., Hurwitz, D.I., Jackson, J.D., et al. (2007). CDD: a conserved 17 domain database for interactive domain family analysis. Nucleic Acids Res. 35, D237-240.

1816 Neuhoff, V., Arold, N., Taube, D., and Ehrhardt, W. (1988). Improved staining of

19 proteins in polyacrylamide gels including isoelectric focusing gels with clear background at 20 nanogram sensitivity using Coomassie Brilliant Blue G-250 and R-250. Electrophoresis 9, 25521262.

2217 Nicolau, E., Kerhoas, L., Lettere, M., Jouanneau, Y., and Marchal, R. (2008).

23 Biodegradation of 2-ethylhexyl nitrate by Mycobacterium austroafricanum IFP 2173. Appl.

24 Environ. Microbiol. 74, 6187-6193. 
118 Sabirova, J.S., Ferrer, M., Regenhardt, D., Timmis, K.N., and Golyshin, P.N. (2006).

2 Proteomic insights into metabolic adaptations in Alcanivorax borkumensis induced by alkane

3 utilization. J. Bacteriol. 188, 3763-3773.

419 Sambrook, J., Fritsch, E.F., and Maniatis, T., eds. (1989). Molecular Cloning: a laboratory

5 manual. Second edition. Cold Spring Harbor Laboratory Press, Cold Spring Harbor, NY.

620 Schagger, H. (2006). Tricine-SDS-PAGE. Nat. Protoc. 1, 16-22.

721 Schneiker, S., Dos Santos, V.A., Bartels, D., Bekel, T., Brecht, M., Buhrmester, J.,

8 Chernikova, T.N., Denaro, R., Ferrer, M., Gertler, C., et al. (2006). Genome sequence of the

9 ubiquitous hydrocarbon-degrading marine bacterium Alcanivorax borkumensis. Nat. Biotechnol.

$10 \quad 24,997-1004$.

1122 Sokolovska, I., Rozenberg, R., Riez, C., Rouxhet, P.G., Agathos, S.N., and Wattiau, P. 12 (2003). Carbon source-induced modifications in the mycolic acid content and cell wall 13 permeability of Rhodococcus erythropolis E1. Appl. Environ. Microbiol. 69, 7019-7027.

1423 Solano-Serena, F., Marchal, R., Heiss, S., and Vandecasteele, J.P. (2004). Degradation of 15 isooctane by Mycobacterium austroafricanum IFP 2173: growth and catabolic pathway. J. Appl. 16 Microbiol. 97, 629-639.

1724 Solano-Serena, F., Nicolau, E., Favreau, G., Jouanneau, Y., and Marchal, R. (2008). 18 Biodegradability of 2-ethylhexyl nitrate (2-EHN), a cetane improver of diesel oil. Biodegradation $1920,85-94$.

2025 Szybist, J.P., Boehman, A.L., Taylor, J.D., and McCormick, R.L. (2005). Evaluation of 21 formulation strategies to eliminate the biodiesel NOx effect. Fuel Proces. Technol. 86, 1109221126.

2326 The American Chemistry Council Petroleum additives panel (2006). High Production 24 Volume Challenge program Final Submission for Nitric Acid, 2-Ethylhexyl Ester, pp. 11. 
127 Tusnady, G.E., and Simon, I. (2001). The HMMTOP transmembrane topology prediction

2 server. Bioinformatics 17, 849-850.

328 van Beilen, J.B., Eggink, G., Enequist, H., Bos, R., and Witholt, B. (1992). DNA

4 sequence determination and functional characterization of the OCT-plasmid-encoded alkJKL

5 genes of Pseudomonas oleovorans. Mol. Microbiol. 6, 3121-3136.

629 van Beilen, J.B., and Funhoff, E.G. (2007). Alkane hydroxylases involved in microbial

7 alkane degradation. Appl. Microbiol. Biotechnol. 74, 13-21.

830 van Beilen, J.B., Funhoff, E.G., van Loon, A., Just, A., Kaysser, L., Bouza, M.,

9 Holtackers, R., Rothlisberger, M., Li, Z., and Witholt, B. (2006). Cytochrome P450 alkane

10 hydroxylases of the CYP153 family are common in alkane-degrading eubacteria lacking integral

11 membrane alkane hydroxylases. Appl. Environ. Microbiol. 72, 59-65.

1231 van Beilen, J.B., Holtackers, R., Luscher, D., Bauer, U., Witholt, B., and Duetz, W.A.

13 (2005). Biocatalytic production of perillyl alcohol from limonene by using a novel

14 Mycobacterium sp. cytochrome P450 alkane hydroxylase expressed in Pseudomonas putida.

15 Appl. Environ. Microbiol. 71, 1737-1744.

1632 van Beilen, J.B., Panke, S., Lucchini, S., Franchini, A.G., Rothlisberger, M., and Witholt,

17 B. (2001). Analysis of Pseudomonas putida alkane-degradation gene clusters and flanking

18 insertion sequences: evolution and regulation of the alk genes. Microbiology 147, 1621-1630.

1933 Wang, R.F., Cao, W.W., and Cerniglia, C.E. (1995). Phylogenetic analysis of polycyclic

20 aromatic hydrocarbon degrading mycobacteria by 16S rRNA sequencing. FEMS Microbiol. Lett.

$21 \quad 130,75-80$.

2234 Zhao, B., and Poh, C.L. (2008). Insights into environmental bioremediation by

23 microorganisms through functional genomics and proteomics. Proteomics 8, 874-881. 


\section{$1 \quad$ Legends to figures}

2 Figure 1: 2D gel map of soluble proteins from M. austroafricanum IFP 2173 induced by 2-EHN.

3 Isoelectric focusing was performed in the $\mathrm{pH}$ range 4 to 7 . A: cells grown on 2-EHN, B: cells 4 grown on acetate. 2-EHN-specific protein spots are numbered in panel A.

6 Figure 2 : Expression of genes relevant to 2-EHN degradation as analyzed by RT-PCR.

7 Reactions were performed as described under Materials and Methods using primers specific to an

8 internal region of the indicated genes. alkB1 and alkB2 designate genes encoding two alkane

9 hydroxylases, while alkH refers to a gene coding for an aldehyde dehydrogenase (see text). RNA

10 used as template was extracted either from 2-EHN exposed cells (lanes $3 \& 4$ ) or from acetate-

11 grown cells (lanes $5 \& 6$ ). The content of each RNA preparation was checked by carrying out a

12 RT-PCR of a portion of 16S RNA. Lanes 3 and 5 are control reactions in which reverse

13 transcriptase was omitted. Lane 1, DNA ladder ; lane 2, PCR amplicon generated from gDNA.

15 Figure 3 : Proposed pathway and enzymes involved in 2-EHN degradation

16 Products: a: 2-ethylhexyl nitrate; b: 2-ethylpentane-1,5-diol; c: 5-(hydroxymethyl)heptanoic

17 acid; d: 5-(hydroxymethyl)heptanoyl CoA; e: 5-(hydroxymethyl)heptan-2-enoyl CoA; f: 318 hydroxy-5-(hydroxymethyl)heptanoyl CoA; g: 5-(hydroxymethyl)-3-ketoheptanoyl CoA; h: 3-

19 (hydroxymethyl)-pentanoyl CoA; i: 3-(hydroxymethyl)-pentanoic acid; j: 4-ethyldihydrofuran$20 \quad 2-(3 \mathrm{H})$ one

21 Enzymes: 1: alkane hydroxylase (AlkB1, AlkB2 or CYP153) and esterase, 2: alcohol

22 dehydrogenase and aldehyde dehydrogenases, 3 and 8: acyl CoA acyltransferase, 4: Acyl CoA

23 dehydrogenase, 5: Enoyl CoA hydratase, 6: Hydroxyacyl CoA dehydrogenase, 7: Thiolase, 9:

24 spontaneous cyclisation. $\downarrow$ Indicates that $\beta$-oxidation is blocked by the ethyl chain in $\beta$ 25 position. 
Table 1: Cytoplasmic proteins up-regulated upon incubation of M. austroafricanum IFP 2173 on 2-EHN

\begin{tabular}{|c|c|c|c|c|c|c|c|c|c|c|}
\hline Enzyme or protein function & Spot \# & $\begin{array}{c}\text { 2-EHN } \\
\text { induction* }\end{array}$ & $\begin{array}{l}{ }^{35} \text { S-labelling } \\
\text { on 2-EHN* }\end{array}$ & $\mathbf{p I}^{\mathbf{b}}$ & $\begin{array}{c}\text { Mol } \\
\text { Mass }^{b}\end{array}$ & Score & $\begin{array}{c}\text { Coverage } \\
(\%)\end{array}$ & Peptides & $\begin{array}{c}\text { SwissProt/ } \\
\text { TrEMBL }\end{array}$ & Micro-organism \\
\hline \multirow{9}{*}{ Acyl-CoA dehydrogenase domain protein } & & & & & & & & & & \\
\hline & E1 & +++ & +++ & 5,3 & 41116 & 186 & 10 & 3 & \multirow{2}{*}{ A4TFJ1 } & \multirow{2}{*}{ M. gilvum PYR-GC } \\
\hline & $\mathrm{E} 2$ & +++ & +++ & 5,4 & & 180 & 9 & 3 & & \\
\hline & E1 & +++ & +++ & 5,3 & 40821 & 133 & 11 & 3 & A3Q1G5 & Mycobacterium sp. JLS \\
\hline & E2 & +++ & +++ & 5,4 & 40989 & 702 & 32 & 10 & A1TCG $6^{\mathrm{c}}$ & M.vanbaalenii PYR-1 \\
\hline & E3 & +++ & +++ & 5,15 & 42234 & 112 & 10 & 2 & A4T8F2 & M. gilvum PYR-GC \\
\hline & E4 & +++ & +++ & 4,8 & 39744 & 265 & 18 & 4 & A1TDA6 ${ }^{\mathrm{c}}$ & M. vanbaalenii PYR-1 \\
\hline & E7 & ++ & ++ & 5,87 & 42108 & 118 & 6 & 2 & A4TFI8 & M. gilvum PYR-GC \\
\hline & E8 & +++ & + & 5,2 & 41520 & 585 & 36 & 9 & $\mathrm{~A} 1 \mathrm{~T} 5 \mathrm{U} 2^{\mathrm{c}}$ & M. vanbaalenii PYR-1 \\
\hline \multirow{4}{*}{ Enoyl-CoA hydratase/isomerase } & E9 & +++ & +++ & 4,9 & 29971 & 133 & 9 & 2 & A1TDW3 & M. vanbaalenii PYR-1 \\
\hline & E10 & - & +++ & 5,1 & 27387 & 121 & 11 & 2 & A4TFL1 & M. gilvum PYR-GC \\
\hline & E9 & +++ & +++ & 4,85 & 27478 & 280 & 22 & 5 & A1TE56 ${ }^{\mathrm{c}}$ & M. vanbaalenii PYR-1 \\
\hline & E9 & +++ & +++ & 4,85 & 26666 & 35 & 5 & 1 & A4TDN8 & M. gilvum PYR-GC \\
\hline 3-hydroxyacyl-CoA dehydrogenase, NAD- & E11 & ++ & ++ & 5,4 & 76177 & 586 & 19 & 11 & \multirow{2}{*}{ A1TF87 } & \multirow{2}{*}{ M. vanbaalenii PYR-1 } \\
\hline binding & E12 & ++ & ++ & 5,4 & & 381 & 11 & 7 & & \\
\hline Acetyl-CoA C-acyltransferase (EC & E1 & +++ & +++ & 5,4 & 39836 & 591 & 32 & 9 & A1TDW $4^{\mathrm{c}}$ & M. vanbaalenii PYR-1 \\
\hline 2.3.1.16) & E13 & ++ & +++ & 4,9 & 42130 & 189 & 11 & 3 & A1TF88 & M. vanbaalenii PYR-1 \\
\hline Acyl-ACP thioesterase & E10 & - & +++ & 5,3 & 31192 & 117 & 8 & 2 & A1T388 & M. vanbaalenii PYR-1 \\
\hline
\end{tabular}




\begin{tabular}{|c|c|c|c|c|c|c|c|c|c|c|}
\hline Enzyme or protein function & Spot \# & $\begin{array}{c}\text { 2-EHN } \\
\text { induction* }\end{array}$ & $\begin{array}{l}{ }^{35} \text { S-labelling } \\
\text { on 2-EHN* }\end{array}$ & $\mathbf{p I}^{\mathbf{b}}$ & $\begin{array}{c}\text { Mol } \\
\text { Mass }^{b}\end{array}$ & Score & $\begin{array}{c}\text { Coverage } \\
(\%)\end{array}$ & Peptides & $\begin{array}{l}\text { SwissProt/ } \\
\text { TrEMBL }\end{array}$ & Micro-organism \\
\hline FAD-dependent pyridine nucleotide- & E15 & +++ & +++ & 5,55 & 42755 & 319 & 18 & 5 & \multirow{2}{*}{ A4TFL9 } & \multirow{2}{*}{ M. gilvum PYR-GC } \\
\hline disulphide oxidoreductase & E7 & +++ & + & 5,8 & & 152 & 9 & 3 & & \\
\hline \multirow{2}{*}{ Short-chain dehydrogenase/reductase } & E17 & +++ & ++ & 4,9 & 29920 & 164 & 15 & 3 & $\mathrm{~A} 1 \mathrm{~T} 1 \mathrm{~A} 7^{\mathrm{c}}$ & M. vanbaalenii PYR-1 \\
\hline & E18 & +++ & +++ & 4,9 & 30143 & 102 & 10 & 2 & Q1BFX1 & Mycobacterium sp. MCS \\
\hline (S)-2-hydroxy-acid oxidase & E30 & +++ & - & 7 & 42022 & 169 & 10 & 3 & A1T4N1 & M. vanbaalenii PYR-1 \\
\hline Dihydrolipoamide dehydrogenase & E22 & ++ & ++ & 5,6 & 49719 & 370 & 18 & 6 & A1T382 & M. vanbaalenii PYR-1 \\
\hline \multicolumn{11}{|l|}{ Lysine biosynthesis } \\
\hline Dihydrodipicolinate synthase & E24 & ++ & - & 5,4 & 31436.7 & 163 & 12 & 3 & A1T7Q1 & M. vanbaalenii PYR-1 \\
\hline $\begin{array}{c}\text { Dihydrodipicolinate reductase (EC } \\
\qquad 1.3 .1 .26)\end{array}$ & E23 & ++ & - & 4,8 & 25816 & 59 & 8 & 1 & $\mathrm{~A} 1 \mathrm{~T} 7 \mathrm{~N} 8$ & M. vanbaalenii PYR-1 \\
\hline \multicolumn{11}{|l|}{ Protein synthesis } \\
\hline Serine-tRNA ligase (EC 6.1.1.11) & E25 & +++ & +++ & 4,8 & 60542.4 & 128 & 6 & 2 & A1TGX4 & M. vanbaalenii PYR-1 \\
\hline Ketol-acid reductoisomerase (EC 1.1.1.86) & E3 & +++ & +++ & 5,2 & 36513 & 158 & 5 & 2 & Q1BAR7 & Mycobacterium sp. MCS \\
\hline \multicolumn{11}{|l|}{ Nitrogen assimilation } \\
\hline Alanine dehydrogenase (EC 1.4.1.1) & E28 & - & +++ & 5,2 & 38907 & 203 & 11 & 3 & A1T7L9 & M. vanbaalenii PYR-1 \\
\hline \multicolumn{11}{|l|}{ Oxidative phosphorylation } \\
\hline $\begin{array}{l}\text { ATP synthase epsilon chain (EC 3.6.3.14) } \\
\text { (ATP synthase F1 sector epsilon subunit) }\end{array}$ & E29 & +++ & +++ & 4,8 & 13330 & 85 & 9 & 1 & P45822 & M. leprae $\mathrm{TN}$ \\
\hline \multicolumn{11}{|l|}{$\mathrm{CO}_{2}$ hydratation } \\
\hline Carbonic anhydrase & E31 & ++ & ++ & 4,8 & 18225 & 272 & 33 & 6 & A1TDF0 & M. vanbaalenii PYR-1 \\
\hline \multicolumn{11}{|l|}{ Glycolysis / glyconeogenesis } \\
\hline \multirow{2}{*}{ Phosphoglycerate kinase (EC 2.7.2.3) } & E32 & +++ & +++ & 4,7 & \multirow{2}{*}{42102} & 435 & 24 & 6 & \multirow{2}{*}{ A1T8L1 } & \multirow{2}{*}{ M. vanbaalenii PYR-1 } \\
\hline & E6 & +++ & +++ & 4,75 & & 572 & 28 & 8 & & \\
\hline
\end{tabular}




\begin{tabular}{|c|c|c|c|c|c|c|c|c|c|c|}
\hline Enzyme or protein function & Spot \# & $\begin{array}{c}\text { 2-EHN } \\
\text { induction* }\end{array}$ & $\begin{array}{l}{ }^{35} \text { S-labelling } \\
\text { on 2-EHN* }\end{array}$ & $\mathbf{p} \mathbf{I}^{\mathbf{b}}$ & $\begin{array}{c}\text { Mol } \\
\text { Mass }^{\mathrm{b}}\end{array}$ & Score & $\begin{array}{c}\text { Coverage } \\
(\%)\end{array}$ & Peptides & $\begin{array}{l}\text { SwissProt/ } \\
\text { TrEMBL }\end{array}$ & Micro-organism \\
\hline \multicolumn{11}{|l|}{ Stress response } \\
\hline Heat shock protein Hsp20 & E26 & +++ & +++ & 4,8 & 15648.4 & 177 & 27 & 3 & $\mathrm{~A} 1 \mathrm{~T} 4 \mathrm{~V} 8^{\mathrm{c}}$ & M. vanbaalenii PYR-1 \\
\hline UspA & E24 & ++ & - & 5,4 & 31354 & 85 & 5 & 1 & A1T4W2 & M. vanbaalenii PYR-1 \\
\hline \multicolumn{11}{|l|}{ Miscellaneous } \\
\hline Putative esterase precursor & E18 & +++ & +++ & 5 & 35010 & 79 & 6 & 1 & A1T6C2 & M. vanbaalenii PYR-1 \\
\hline Chloride peroxidase (EC 1.11.1.10) & E19 & ++ & - & 5,7 & 30410 & 173 & 15 & 3 & A1T5E7 & M. vanbaalenii PYR-1 \\
\hline Antibiotic biosynthesis monooxygenase & E16 & +++ & +++ & 4,8 & 11741 & 56 & 16 & 1 & Q1B2M9 & Mycobacterium sp. MCS \\
\hline Allophanate hydrolase subunit 1 & E10 & +++ & +++ & 5,3 & 25092 & 142 & 10 & 2 & A1T1V3 & M. vanbaalenii PYR-1 \\
\hline \multirow{2}{*}{ Fumarate lyase } & E20 & +++ & ++ & 5,1 & 49944 & 579 & 24 & 10 & \multirow{2}{*}{$\mathrm{A} 1 \mathrm{TE} 24^{\mathrm{c}}$} & \multirow{2}{*}{ M. vanbaalenii PYR-1 } \\
\hline & E21 & +++ & ++ & 5,1 & 49944 & 538 & 27 & 8 & & \\
\hline $\mathrm{HpcH} / \mathrm{HpaI}$ aldolase & E23 & ++ & - & 4,8 & 29032 & 202 & 13 & 4 & A1TCG4 & M. vanbaalenii PYR-1 \\
\hline Ribonuclease PH (EC 2.7.7.56) & E23 & ++ & - & 4,8 & 27449 & 75 & 5 & 2 & A1T7Q1 & M. vanbaalenii PYR-1 \\
\hline Glycyl-tRNA synthetase, alpha2 dimer & E22 & ++ & ++ & 5,6 & 59543 & 405 & 18 & 7 & A1ТВP9 & M. vanbaalenii PYR-1 \\
\hline $\begin{array}{c}\text { 3-hydroxyisobutyrate dehydrogenase } \\
\text { precursor }\end{array}$ & E23 & ++ & - & 4,8 & 29262 & 195 & 16 & 3 & A1T4U4 & M. vanbaalenii PYR-1 \\
\hline $\begin{array}{c}\text { Cyclic nucleotide-binding:regulatory } \\
\text { protein, Crp }\end{array}$ & E27 & +++ & - & 9,6 & 24776 & 409 & 40 & 7 & A1T6A5 & M. vanbaalenii PYR-1 \\
\hline $\begin{array}{c}\text { Phosphoribosyltransferase: Erythromycin } \\
\text { esterase }\end{array}$ & E12 & ++ & ++ & 5,4 & 74587 & 49 & 2 & 1 & $\mathrm{~A} 1 \mathrm{~T} 4 \times 7^{\mathrm{c}}$ & M. vanbaalenii PYR-1 \\
\hline
\end{tabular}

*Spot intensity was estimated from visual inspection of stained gels or autoradiographies $:+,++,+++$ stand for small, medium size and large spots,

respectively. (-) means undetected spot.

${ }^{\mathrm{b}}$ Theoretical values calculated on the basis of deduced polypeptide sequences.

${ }^{\mathrm{c}}$ These protein entries also appear in the list of 2-EHN-induced proteins identified by shotgun analysis (Table S3) 
Table 2: Functional classification of proteins more abundant or exclusively dete EHN

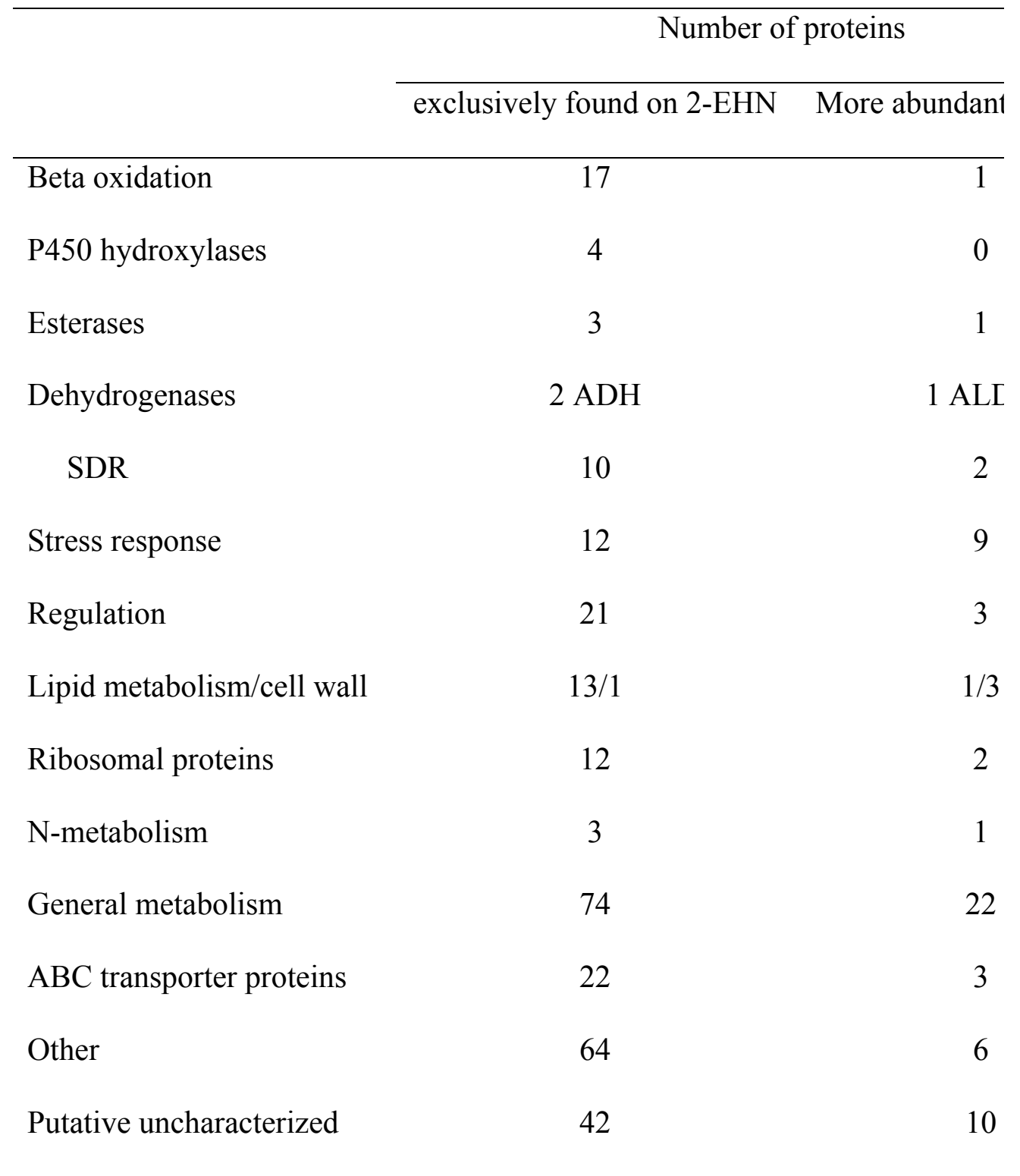




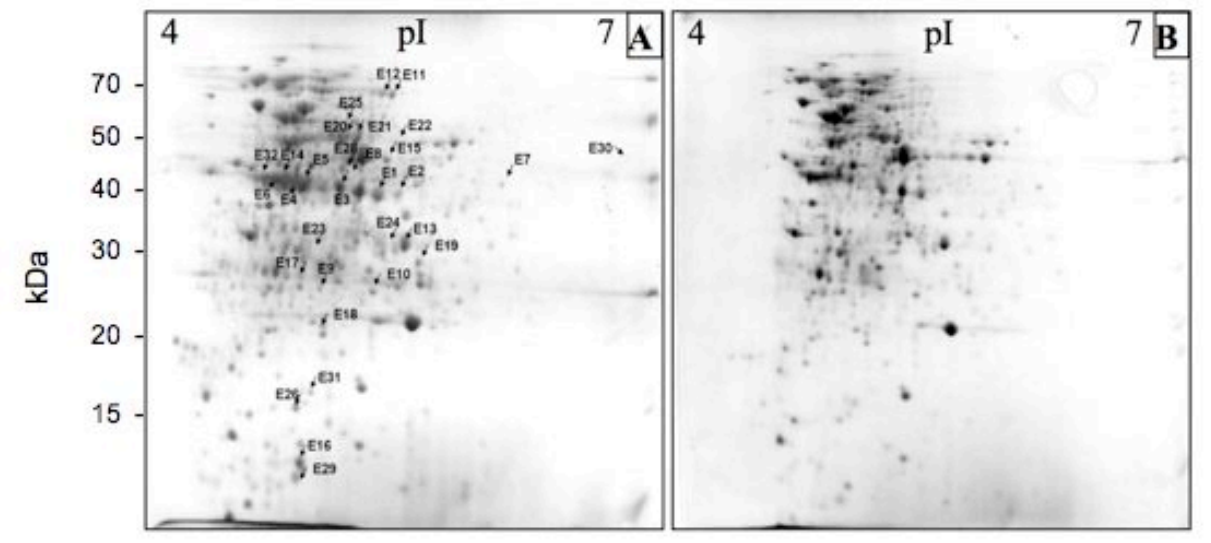

Fig. 1, Nicolau et al. 
Fig. 2, Nicolau et al.

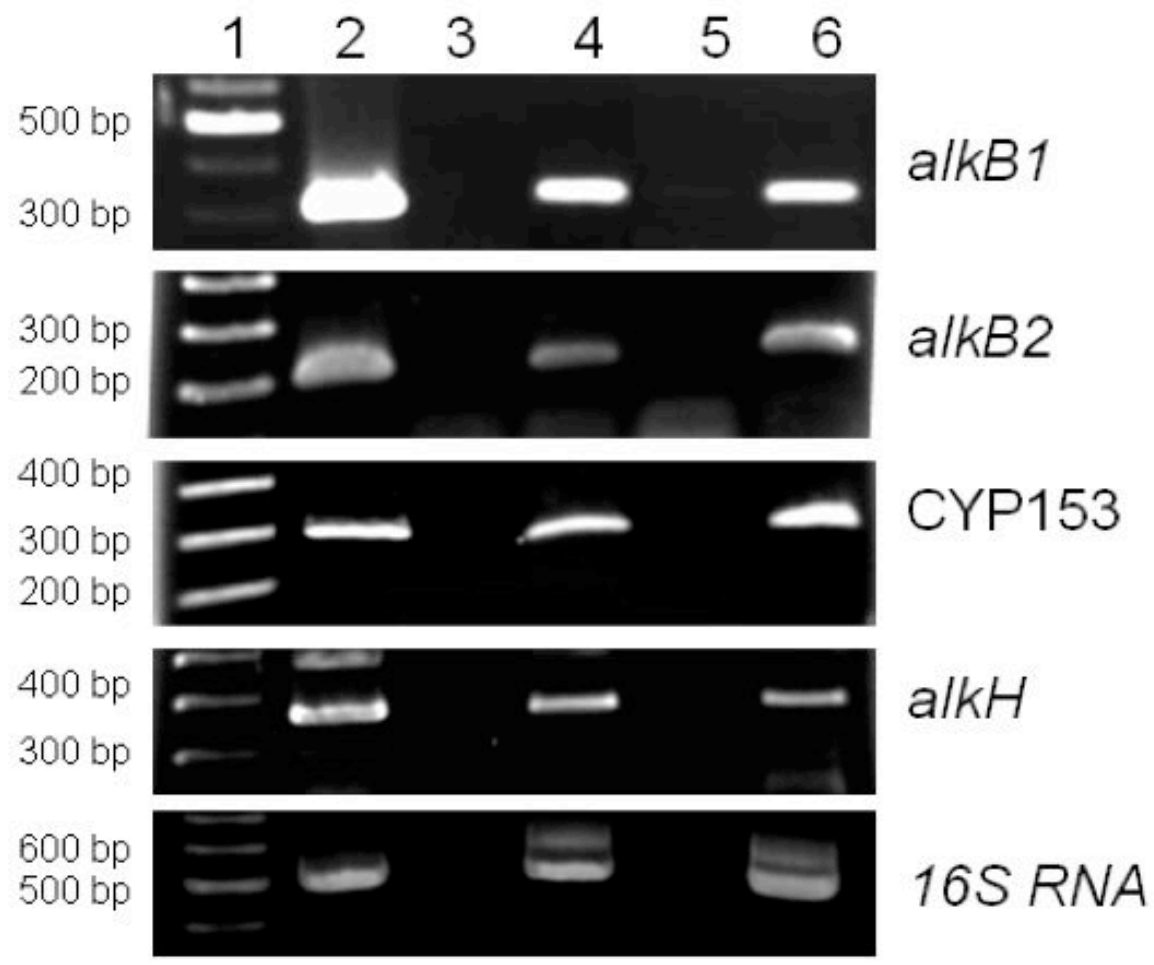

Fig. 3, Nicolau et al.

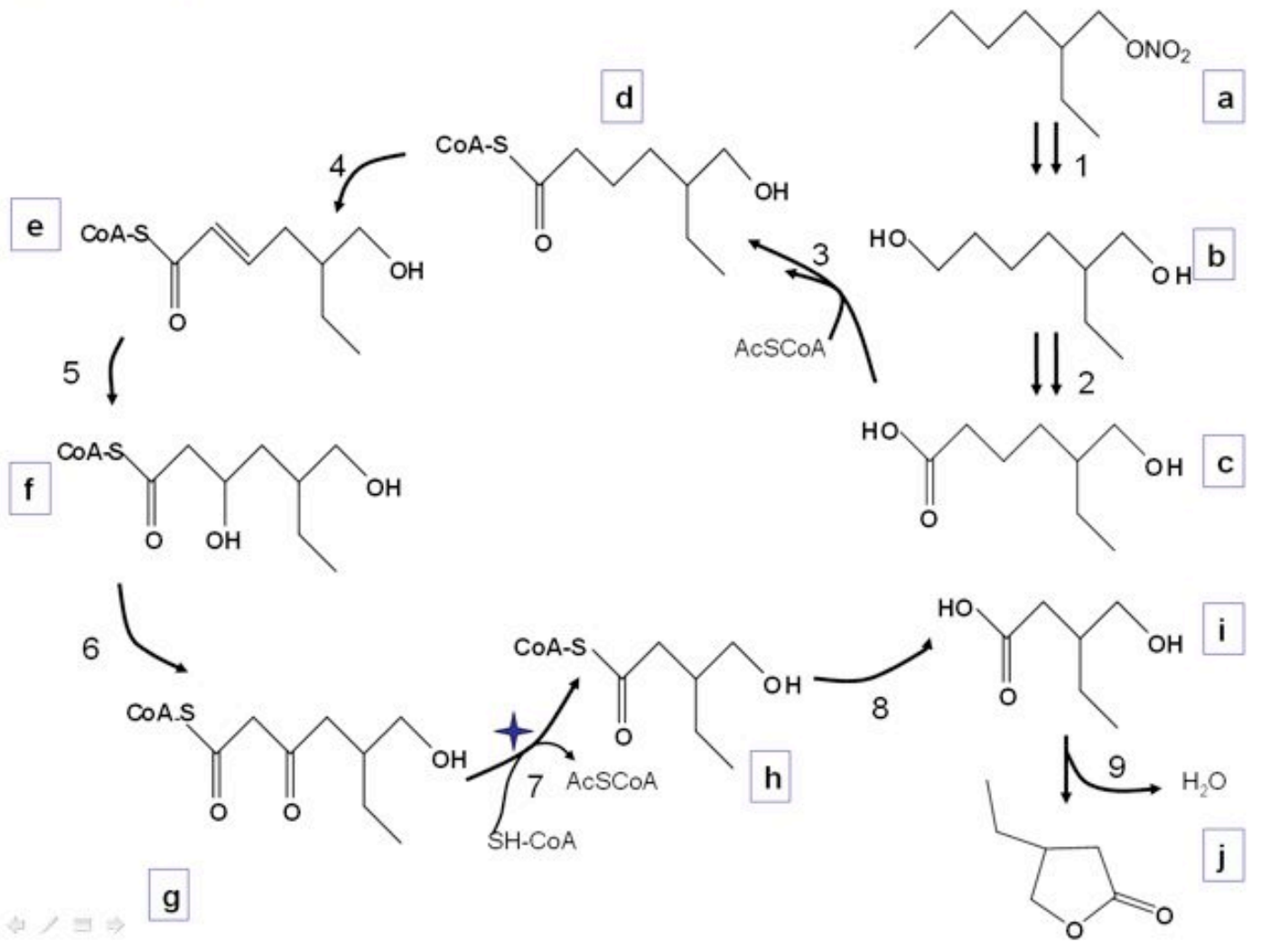

